\title{
Estimation of Body Height from Head Length among Dental Students of a Dental College
}

\author{
Bipana Manandhar, 'Ritee Shrestha' \\ 'Department of Anatomy, Kantipur Dental College, Basundhara, Kathmandu, Nepal.
}

\begin{abstract}
Introduction: Body height is an important measure of physical identity. Height exhibits a dimensional relationship with various parts of the body. This relationship helps to calculate height from dismembered and mutilated body parts in forensic examinations. As the cranial dimensions are more reliable and precise means of predicting the stature, this study was undertaken to find the relation between head length and height and to derive a regression formula for the estimation of height from head length among dental students.
\end{abstract}

Methods: This descriptive cross-sectional study was conducted among 150 dental students of age group 18-21 years in the Department of Anatomy, Kantipur Dental College Teaching Hospital and Research Center, Basundhara, Kathmandu. The head length was measured with the help of spreading caliper. Height was measured with the help of a standard height measuring instrument. The head length and the height of the students were measured in centimeters. Data obtained were analyzed to find the correlation between head length and height and to derive a regression equation for the estimation of height.

Results: A significant positive correlation was observed between head length and height $(\mathrm{r}=0.734$, $\mathrm{P}<0.001)$. The regression equation for body height and head length including both sexes and all age groups of dental students was found to be $y=12.9+8.45 \mathrm{x}$ where $\mathrm{x}$ is head length and $\mathrm{y}$ is body height.

Conclusions: It was observed in the present study that there was a significant positive correlation between height and head length in all the age groups indicating that head length is a reliable indicator in estimation of height.

Keywords: head length; height; Nepal; regression equation.

\section{INTRODUCTION}

Body height is one of the useful anthropometric parameter for individual identification. ${ }^{1}$ Establishing the identity of an individual from mutilated body fragments is an important aspect in natural disasters. ${ }^{2}$ Body height has a definite and proportional biological relationship with each and every part of the human body like head, face, trunk and extremities. ${ }^{3}$ Interrelationship between body height and head length measurements can be used to estimate one from another. ${ }^{4}$

There is no universally applicable formula derived for the estimation of body height from different body parts as

Correspondence: Dr. Bipana Manandhar, Department of Anatomy, Kantipur Dental College, Basundhara, Kathmandu, Nepal. Email: bips_123@hotmail.com, Phone: +977-9849195803. 
the relationship between height and different body parts differ according to race, ethnicity, age and sex. The authors could not find any such study correlating head length with height in context to Nepalese population.

Hence, the present study attempts to find the correlation between head length and body height and estimate body height from head length among dental students of different age group.

\section{METHODS}

This descriptive cross-sectional study was conducted among 150 dental students (107 females and 43 males) of age ranging from 18-21 years in the Department of Anatomy, Kantipur Dental College, Basundhara, Kathmandu, Nepal from February 2018 to June 2018. The study was conducted with the approval of Institutional Review Committee of Kantipur Dental College.

The dental students were selected because of easy access and the students of age group 18-21 years were included as the bone growth usually has ceased after the age of puberty. The students were duly informed about the procedure and the informed consent was taken prior to the procedure. The students with normal cranio-facial skeleton and stature were included in the study. The students with growth disorders, deformities of cranial bone and previous history of craniofacial trauma and surgery were excluded.
Convenience (Non-probability) sampling technique was used to collect data. Sample size was calculated by utilizing following Slovin's ${ }^{5}$ formula based on total number of dental students of Kantipur Dental College.

$$
\text { Sample size, } \begin{aligned}
\mathrm{n}= & \frac{\mathrm{N}}{1+\mathrm{Ne}^{2}} \\
& =146 \\
& \sim 150
\end{aligned}
$$

where population size $(N)=230$, margin of error $(e)$ $=0.05$.

Measurements of both head length and the height were recorded in centimetres $(\mathrm{cm})$. The data obtained were analysed statistically using Statistical Package for Social Sciences (SPSS) version 16 to find the correlation coefficient between head length and height and to derive a regression equation for estimating the height from head length. $\mathrm{P}<0.05$ was considered statistically significant.

The regression formula is $y=a+b x$, where $b$ stands for slope, a stand for intercept/constant, $x$ stands for mean head length and $y$ stands for height.

\section{RESULTS}

The total number of dental students who participated in the study was 150 out of which 107 (71.33\%)

\begin{tabular}{|c|c|c|c|c|}
\hline $\begin{array}{l}\text { Age group } \\
\text { (years) }\end{array}$ & Frequency n (\%) & Sex & $\begin{array}{l}\text { Mean } \pm \text { SD } \\
\text { of height }(\mathrm{cm})\end{array}$ & $\begin{array}{l}\text { Mean } \pm \text { SD } \\
\text { of head length }(\mathrm{cm})\end{array}$ \\
\hline & $43(28.66)$ & Male & $169.45 \pm 7.06$ & $18.30 \pm 0.85$ \\
\hline \multirow[t]{3}{*}{$18-21$} & 107 (71.33) & Female & $160.27 \pm 10.38$ & $17.50 \pm 0.81$ \\
\hline & 150 & Total & $162.90 \pm 10.40$ & $17.73 \pm 0.90$ \\
\hline & $5(22.72)$ & Male & $173.33 \pm 3.63$ & $18.46 \pm 0.77$ \\
\hline \multirow[t]{3}{*}{18} & $17(77.27)$ & Female & $164.37 \pm 9.26$ & $17.67 \pm 0.77$ \\
\hline & 22 & Total & $164.62 \pm 12.64$ & $17.73 \pm 1.08$ \\
\hline & $7(13.20)$ & Male & $166.02 \pm 6.54$ & $18.15 \pm 0.99$ \\
\hline \multirow[t]{3}{*}{19} & $46(86.79)$ & Female & $158.84 \pm 12.05$ & $17.28 \pm 0.82$ \\
\hline & 53 & Total & $159.79 \pm 11.68$ & $17.39 \pm 0.88$ \\
\hline & $16(35.55)$ & Male & $165.30 \pm 7.49$ & $17.89 \pm 0.84$ \\
\hline \multirow[t]{2}{*}{20} & $29(64.44)$ & Female & $161.36 \pm 6.87$ & $17.79 \pm 0.68$ \\
\hline & 45 & Total & $162.76 \pm 7.26$ & $17.82 \pm 0.73$ \\
\hline
\end{tabular}
were females and $43(28.66 \%)$ were males. They were

grouped in different age group of 18-21 years.

Table 1. Mean and standard deviation of height and head length. 
Manandhar et al. Estimation of Body Height from Head Length among Dental Students of a Dental College

\begin{tabular}{|c|c|c|c|c|c|c|}
\hline 21 & $\begin{array}{l}15(50) \\
15(50) \\
30\end{array}$ & $\begin{array}{l}\text { Male } \\
\text { Female } \\
\text { Total }\end{array}$ & \multirow[b]{2}{*}{21} & $\begin{array}{l}\text { Male } \\
\text { Female } \\
\text { Total }\end{array}$ & $\begin{array}{l}0.700 \\
0.648 \\
0.661\end{array}$ & $<0.001$ \\
\hline $\begin{array}{l}\text { The } \\
\text { and }\end{array}$ & $\begin{array}{l}\text { and sta } \\
\text { the den }\end{array}$ & $\begin{array}{l}\text { f height } \\
\text { arouped }\end{array}$ & & $\begin{array}{l}\text { Male } \\
\text { Female } \\
\text { Total }\end{array}$ & $\begin{array}{l}0.187 \\
0.570 \\
0.741\end{array}$ & $<0.001$ \\
\hline
\end{tabular}
according to age and gender is presented (Table 1). The mean and standard deviation of height and head length of all the students was found to be $162.90 \pm 10.40 \mathrm{~cm}$ and $17.73 \pm 0.90 \mathrm{~cm}$ respectively. The mean height and head length were measured to be larger in males than in females (Table1).

\begin{tabular}{|llll|}
\hline \multicolumn{3}{|l|}{ Table 2. Correlation coefficient and statistical } \\
significance.
\end{tabular}

The head length showed a positive and significant correlation with height in all the age groups (Table 2, Figure 1).

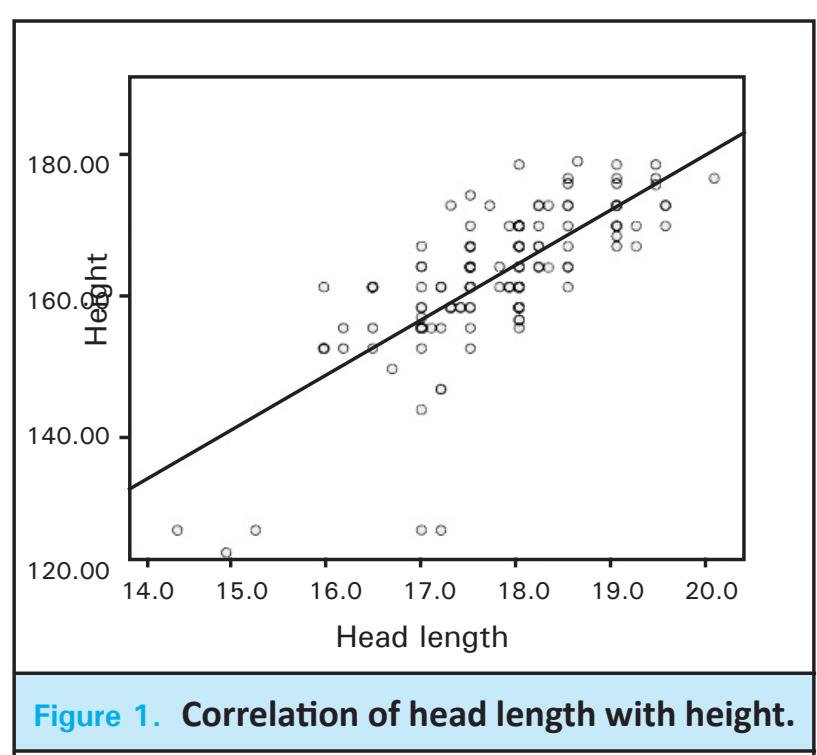

Estimated height was calculated by using a regression equation, $y=a+b x$ by putting the values of regression constant (a) and regression coefficient (b) from Table 3 and the value of mean head length ( $x$ ) from Table 1. The measured and estimated height was found to be nearly equal in individual sex of all age groups (Table 3 ).

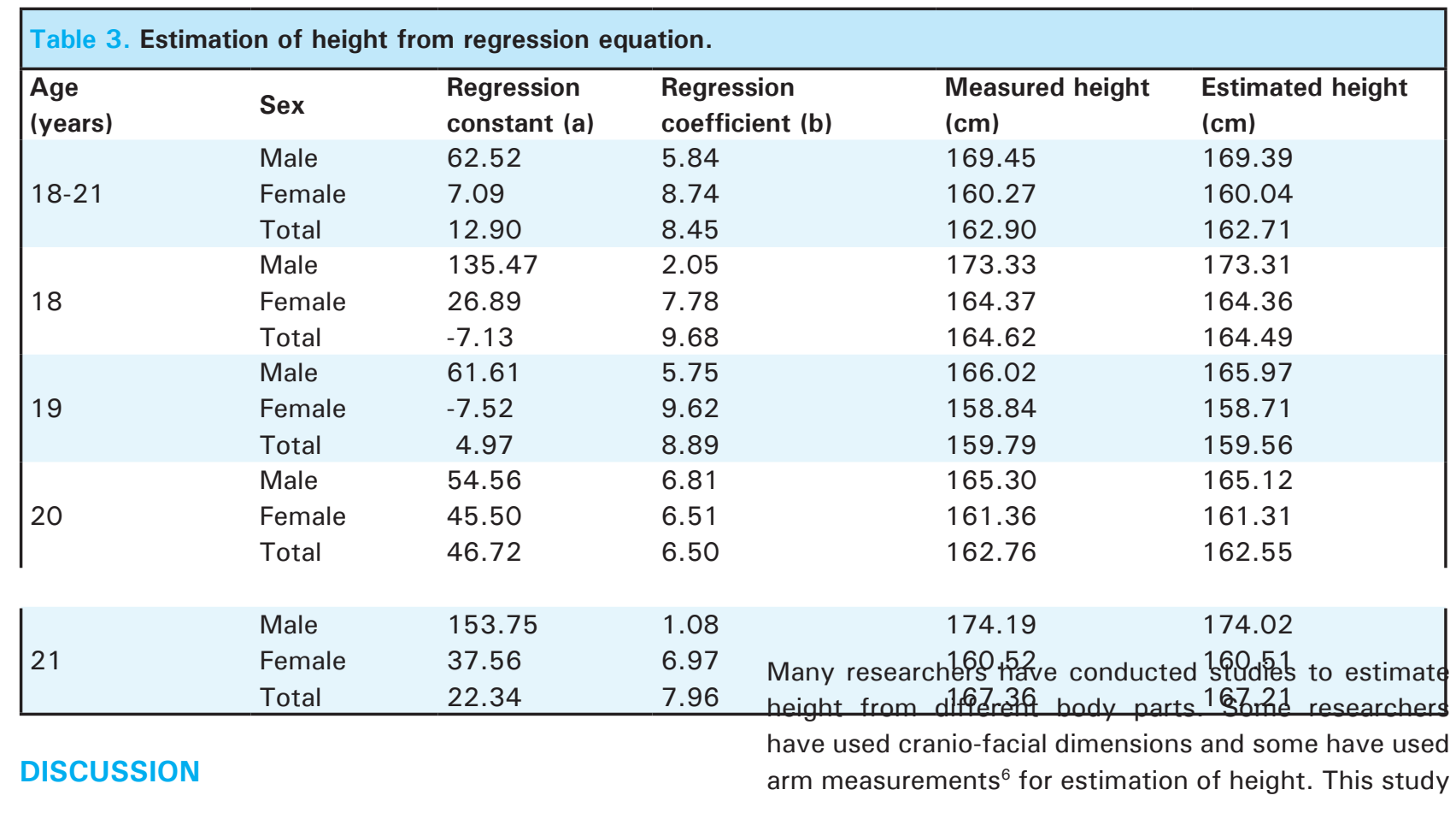


was undertaken to estimate height from head length by using the regression equation. Dimensional relationships between the body segments and the whole body have been of interest to artists, scientists, anatomists, anthropologists and medicolegistics for long time. ${ }^{7}$ It is worthy to note that there are various factors such as genetic, nutrition, geographical location, physical activity and various races which affect the anthropometric data. $^{8}$

The present study found that head length had a strong and significant positive correlation with the height and there was no significant difference observed in estimated and measured height in dental students of all age groups. ${ }^{9}$ Our study with correlation coefficient of head length with height $(r=0.73)$ found similarity with the studies carried out in medical students belonging to various regions of Gujarat, India $(r=0.53),{ }^{9}$ male medical students in Uttar Pradesh, India $(r=0.74),{ }^{10}$ and medical students belonging to Punjab, India $(r=0.52) .{ }^{11}$ This study was consistent with the study conducted on young adults of Efik and Ibibo, two different ethnic groups of Nigeria ${ }^{12}$ in which a significant correlation between body height and head circumference, length and width was observed.

Our study was in accordance with a cross-sectional study among medical students in Belgaum, India ${ }^{13}$ in which head length from nasion to inion showed a positive correlation with stature for male, female and combined with correlation coefficient of 0.507 in males and 0.440 in females and $P<0.001$. The present study found resemblance with a study among medical students of cosmopolitan origin of Uttar Pradesh, India ${ }^{14}$ which showed a significant positive correlation of height with both head length and head breadth. Our study revealed that cranial dimension, head length is a statistically significant predictor of height which was found similar with the study conducted on 60 patients in Ghaziabad, India ${ }^{15}$ and on 200 medical students at S.M.S. Medical College, Jaipur, Rajasthan. ${ }^{16}$

The present study with correlation coefficient $(r=0.73$ ) was dissimilar with the study conducted on individuals aged 18-25 years in Ramaiah Medical College, Bengaluru, India ${ }^{17}$ in which a weak positive correlation was observed between height and head length $(r=0.27)$. Our study was not in accordance with the study carried out on Bangladeshi Garo adult females ${ }^{18}$ with correlation coefficient $(r=-0.02)$ in which head length did not reach statistically significant level with their height. This study was in contrast with the study conducted in female medical students of Uttar Pradesh, India ${ }^{19}$ in which head length was observed to be of little importance for estimation of height.

Our study was not in consistent with the study conducted on Indo-Mauritian population in Mauritius ${ }^{20}$ in which accurate stature estimation was not found possible from cephalo-facial dimensions. Our study found no similarity with a research conducted on 100 healthy individuals in Mumbai, India ${ }^{20}$ which did not show the positive correlation of head dimensions with stature.

In the present study, only 150 students with age group 18-21 years were included and ethnic or regional specific regression formulae was also not derived so further studies with larger samples including individuals of age above 21 years of different ethnic groups of Nepal, could be conducted for more better result. Applicability of anthropometric measurements of this study in living may practically differ in deceased individuals. The present study is a preliminary one conducted in Nepal hence need to be followed up by other studies to address the above limitations.

\section{CONCLUSIONS}

The present study showed a positive significant correlation between height and head length indicating that the regression equation from head length can be used as a reliable indicator in prediction of height. The prediction of height from incomplete and decomposed cranial remains is essential in establishing the identity of unknown individuals in incident of murders, accidents or natural disasters. If one of the parameter is known the other can be known by applying the regression equation when the prediction of the height from incomplete and decomposed cranial remains is essential in forensic and anthropology sciences.

\section{ACKNOWLEDGEMENTS}

We would like to thank all the students who participated in our research work.

\section{Conflict of Interest: None.}

\section{REFERENCES}

1. Yadav AB, Yadav SK, Kedia NB, Singh AK. An odontometric approach for estimation of stature in Indians: Cross-sectional analysis. J Clin Diagn Res. 2016 Mar;10(3):24-6. [PubMed| $\underline{\text { Full Text } \mid \text { DOI] }}$

2. Chikhalkar BG, Mangaonkar AA, Nanandkar SD, Peddawad RG. Estimation of stature from measurements of long bones, 
hand and foot dimensions. J Indian Acad Forensic Med. 2010;32(4):329-33. [Full Text]

3. Badiye A, Bansal H. An estimation of correlation between head length and stature of the children aged between 6-10 years. Res J Forensic Sci. 2013 Apr;1(2):1-5. [Full Text]

4. Mansur DI, Haque MK, Sharma K, Karki RK, Khanal K, Karna R. Estimation of stature from foot length in adult Nepalese population and its clinical relevance. Kathmandu Univ Med J. 2012 Mar;10(1):16-9. [ uㅏbMed | Full Text | DOI]

5. Putra AN, Welly J. Analysing engagement of outsource employee study case: PT Bravo Humanika Persada. J Business Management. 2015;4(8):901-12. [ull Text]

6. Lahner CR, Kassier SM, Veldman FJ. Estimation of true height: a study in population-specific methods among young South African adults. Public Health Nutr. 2017;20(2):210-19. [PubMed | Full Text | DOI]

7. Kumar S, Srivastava AK, Sahai MKB. Estimation of stature by anthropometric examination of forearm and hand. $\mathrm{J}$ Indian Acad Forensic Med. 2010;32(1):62-5. [Full Text]

8. Akhlaghi M, Hajibeygi M, Zamani N, Moradi B. Estimation of stature from upper limb anthropometry in Iranian population. J Forensic Leg Med. 2012 Jul;19(5):280-4. [PubMed | DOI]

9. Jadav HR, Shah GV. Determination of personal height from the length of head in Gujarat region. J Anat Soc India. 2004;53(1):20-21.[Full Text]

10. Singh R. Estimation of stature and age from head dimensions in Indian population. Int J Morphol. 2013;31(4):1185-90. [Full Text]

11. Seema, Mahajan A. Estimation of personal height from the length of head in Punjab zone. Int J Plant Animal Env Sci. 2011 Nov;1(3):205-8. [Full Text]

12. Eboh DEO. Determination of stature from combined maxillary anterior teeth and head dimensions among the Efik and Ibibio of South Nigeria. Annals Bioanthropol. 2016 Sept;4(1):53-9. [Full Text]

13. Kadagoudar S, Manjulabai KH, Hallikeri VR. Estimation of stature by Nasion-Inion head length in South Indian population - A cross sectional study. Medica Innovatica. 2014 Dec;3(2):9-11. [Full Text]

14. Agarwal S, Agarwal SK, Jain SK. Correlation between the stature and cranial measurements in population of North India. Acta Med Int. 2014 Jul;1(2):99-102. [Full Text]

15. Gupta A, Kumar K, Shetty DC, Wadhwan V, Jain A, Khanna $\mathrm{SH}$. Stature and gender determination and their correlation using odontometry and skull anthropometry. J Forensic Dent Sci. 2014 Aug;6(2):101-6. [PubMed | Full Text | DOI]

16. Garg P, Chauhan S. Determination of stature from the length of head in population of Rajasthan. Int J Med Res Prof. 2016;2(2):154-6. [Full Text]

17. Shankar GS, Shankar VV, Shetty S, Radhika K. Correlation of human height with head length in Indian individuals. Int J Anat Res. 2017 Dec;5(4.3):4723-6. [Full Text | DOI]

18. Akhter Z, Banu LA, Alam MM, Rahman MF. Stature estimation from craniofacial anthropometry in Bangladeshi Garo adult females. Mymensingh Med J. 2012 Jul;21(3):479-84. [PubMed]

19. Singh R. Estimation of stature and age from head dimensions in Indian population. Int J Morphol. 2013;31(4):1185-90. [Full Text]

20. Agnihotri AK et al. Estimation of stature from cephalo-facial dimensions by regression analysis in Indo-Mauritian population. J Forensic Leg Med. 2011 May;18(4):167-72. [PubMed | DOI]

21. Hinduja S, Tamgadge S, Tamgadge A. Odontometry and skull anthropometry: A possible tool for stature estimation using minimum armamentarium. Int J Forensic Odontol. 2018 Jun;3(1):6-11. [Full Text]

The Author(s) 2018.

This work is licensed under a Creative Commons Attribution 4.0 International License. The images or other third party material in this article are included in the article's Creative Commons license, unless indicated otherwise in the credit line; if the material is not included under the Creative Commons license, users will need to obtain permission from the license holder to reproduce the material. To view a copy of this license, visit http://creativecommons.org/licenses/by/4.0/ 